\title{
A Review of Empirical Studies of the Money Supply Mechanism
}

\section{by ROBERT H. RASCHE}

The use of a reserve aggregate as an operating target raises questions about the interest rate effects of policy actions on the ability of the Federal Reserve to achieve a desired growth in the money stock. Open market operations affect both reserve aggregates and interest rates. Changes in interest rates, in turn, infuence the portfolio decisions of banks and the public, and are believed by some to be a complicating factor in the achievement of a desired money growth. This article strveys empirical evidence on the interest rate sensitivity of the money supply, and concludes that this interest elasticity appears to be extremely low. Hence, this factor should exert a negligible effect on the ability of the Federal Reserve to influence money stock growth through control of a reserve aggregate.

I N RECENT YEARS there has been considerable discussion concerning techniques for conducting monetary policy. The traditional practitioners of the art of policymaking have argued for the use of operating procedures which focus on "money market conditions." At various times this has been construed to mean free reserves, the Treasury bill rate, the federal funds rate, or a combination of these. ${ }^{1}$ Alternatively, it has been argued that the target of monetary policy actions should be a monetary aggregate, and that this target can be achieved by control of some reserve aggregate concept such as the monetary base. ${ }^{2}$

This article surveys the accumulated empirical evidence on the interest sensitivity of some reserve multipliers. If these multipliers are highly sensitive to interest rate changes, then it may be difficult to implement monetary control through the control of reserve aggregates. The available evidence consistently indicates, however, that the interest sensitivity of various multiplier concepts is extremely low. This suggests that control of monetary aggregates through reserve control should not be very difficult to implement. ${ }^{3}$

\section{Conditions Inhibiting Control of the Money Stock}

The issue examined here is the feasibility of control of a monetary aggregate such as the narrowly defined

BStephen H. Axilrod, "The FOMC Directive as Structured in the Late 1960's: Theory and Appraisal," in Open Market Policies and Operating Procedures - Staff Studies (Washington, D.C.: Board of Governors of the Federal Reserve System, 1971 ), pp. $1-36$.

2For example, see Albert E. Burger, Lionel Kalish III, and Christopher T. Babb, "Money Stock Control and Its Implications for Monetary Policy," this Review (October 1971), pp. 6-22.

IIf, however, these multipliers are highly sensitive to interest rate changes, then accurate monetary control through a reserve control procedure requires a precise estimate of the impact of reserve changes on interest rates, in addition to a precise estimate of the interest elasticity of the reserve multiplier. money stock $\left(M_{1}\right)$, given control of some reserve aggregate concept. The problem can be illustrated by the equation

$$
\mathrm{M}=\mathrm{mR}
$$

where " $M$ " is the money stock, "R" is some reserve aggregate concept, and " $\mathrm{m}$ " is the appropriate reserve multiplier. ${ }^{4}$ Two sources of difficulty can arise in such a control procedure.

First there can be systematic feedbacks on " $\mathrm{m}$ " through market forces which tend to offset the expected effect of a change in the reserve aggregate on the money stock. This influence of the behavior of reserves on the value of the multiplier can be stated as

$$
\mathrm{m}=\mathrm{f}(\mathrm{R}) \text {. }
$$

The sources of feedback from changes in " $R$ " to changes in " $\mathrm{m}$ " will vary depending on the choice of a reserve aggregate concept. If the net source base concept is used for " $\mathrm{R}$ ", the associated multiplier $(\mathrm{m})$ is

$$
m=\frac{1+k}{(r-b)(1+t+d)+k}
$$

where " $\mathrm{r}$ " and " $\mathrm{b}$ " are the ratios of bank reserves and member bank borrowings to commercial bank deposits, respectively, "t", " $k$ " and " $d$ ", respectively, are the ratios of time deposits, currency held by the public, and U.S. Government deposits at commercial banks to the demand deposit component of the money supply. Therefore, the important behavioral relationships influencing the stability of the multiplier in the presence

\footnotetext{
"A number of candidates have been proposed for " $R$ " inclucting the monetary base, unborrowed reserves plus currency, total reserves, uborrowed reserves, and reserves available to support private deposits. For a discussion of the relative virtues of many of these, see Richard Davis, "Short-Run Targets for Open Market Operations," in Open Market Policies and Operating Procedures-Staff Studies (Washington, D.C.: Board of Governors of the Federal Reserve System, 1971), pp. 37-45.
} 
of reserve changes are the public's demand for currency and time deposits, banks' demand for excess reserves and borrowings, and the supply of time deposits. ${ }^{5}$

An example of a feedback effect on " $m$ " would be where there exists a sizable short-run interest elasticity of demand for excess reserves by commercial banks. In order to force additional reserves into the banking system to expand the money stock, the Federal Reserve would have to buy Government securities, thus pushing short-term interest rates down. If the amount of excess reserves demanded by banks is very sensitive to changes in short-term interest rates, this interest rate movement would induce banks to hold larger quantities of excess reserves. This portfolio shift then offsets the policy to increase the money stock.

The existence of strong feedback effects on the reserve multiplier does not mean that monetary control through reserve aggregates is impossible. The stronger the feedback, the larger the necessary magnitude of the open market operation required to achieve a given change in the money stock and the larger the associated variance in short-term interest rates.

The second source of difficulty in this type of monetary control procedure is that the relationship between the reserve aggregate and the money stock is subject to random fluctuation. Specifically, we can write

$$
\mathbf{m}_{\mathrm{t}}=\mathbf{f}\left(\mathrm{R}_{\mathrm{t}}\right)+\varepsilon_{\mathrm{t}}
$$

where " $\varepsilon_{\mathrm{t}}$ " is an unknown random disturbance to " $\mathrm{m}_{\mathrm{t}}$ ". If such fluctuations are truly random, then in the long run policymakers should be able to hit the desired average stock of money quite closely. If this random component is large, then in a short time period, such as one or two months, the average " $m$ " could deviate considerably from the forecast " $\mathrm{m}$ " and cause a large average error around the desired path of the money stock.

It can be shown that for a given variance of " $\varepsilon_{t}$ ", under a control procedure such as that recently proposed by Burger, Kalish, and Babb, the variance of the actual path of the money stock around the desired path will depend on the sensitivity of the reserve

5For a detalled discussion of the functional relationship of the multiplier expression to asset holdings of the nonbank public, the banking system, and the Treasury, see Albert E. Burger, The Money Supply Process (Belmont, California: Wadsworth, 1971) especially chaps. 4-5, and Karl Brunner and Allan H. Meltzer, "Liquidity Traps for Money, Bank Credit, and Interest Rates, Journal of Political Economy (January/February 1968), pp. 1-37. multiplier $(\mathrm{m})$ to changes in the reserve aggregate. ${ }^{6}$ The smaller the sensitivity of the multiplier, the smaller will be the variance of the actual money stock around the desired money stock.

\section{The Nature of Available Evidence on Multiplier Sensitivity}

Over the past decade there has been considerable empirical research directed at measuring the relationship between the money stock and various reserve aggregates. This work has evolved primarily from attempts to construct econometric models of basic financial relationships in the U.S. economy. As a by-product, these studies provide information on the interest elasticities of the behavioral parameters of the reserve multiplier, the existence of which cause feedbacks against policy actions as discussed above.

Most of the more detailed studies have worked with quarterly data, which may be too highly aggregated in time to provide information that policymakers desire if the reactions of the banking system and the public are distributed over time. However, studies using shorter time horizons do exist for some components of the money supply mechanism, and these can be used to obtain information on how the estimated elasticities are likely to change as the horizon becomes shorter.

There are several potential sources of feedback which will offset the expected impact of a change in reserve aggregates on the change in the money stock. Some of the feedback, such as a change in the demand for currency and time deposits by the nonbank public as a result of increased economic activity, has been shown to occur only slowly, and does not cause difficulties for short-run control. ${ }^{7}$

The troublesome source of changes in the multiplier relationship is the impact of changes in interest rates on the behavioral parameters in the multiplier. Changes in market interest rates and changes in reserves available to the banking system cannot be controlled simultaneously by the Federal Reserve System. When the Federal Reserve follows a reserve aggregate operating procedure, interest rates are affected by changes in reserves. Under a money market conditions operating strategy, changes in reserve aggregates come about as a result of the attempt to achieve certain

\footnotetext{
"Burger, Kalish, and Babb, "Money Stock Control."

TSee David I. Fand, "Some Implications of Money Supply" Analysis," American Economic Review (May 1967), pp. $380-400$.
} 
levels of interest rates. Hence, if the goal is to control money through changes in reserve aggregates, the major issue is the interest elasticity of the relationship between the money stock and reserve aggregates.

It will be necessary to distinguish between shortrun, or impact, elasticities of the reserve multiplier and long-run, or equilibrium, elasticities. The former include only the impact which comes from the adjustment of economic units to a change in interest rates within one period of time. Many studies, however, have indicated that economic units respond to such changes with a distributed lag; that is, part of the response takes place in the same period, and the remainder of the response takes place over several periods following a change in interest rates. The impact, or short-run, interest elasticity is the percentage change in the reserve multiplier with respect to a percentage change in interest rates within the time period in which the interest rate changes. The equilibrium, or long-run, elasticity is the total response of the reserve multiplier after economic units have had sufficient time to adjust to a new portfolio equilibrium. ${ }^{8}$

In the studies cited below, estimates have been obtained for the interest elasticity of the money stock for given values of various reserve aggregates. Thus, the money stock elasticities computed are the interest elasticities of the reserve multiplier.

\section{Interest Elasticity Estimates From Data Prior to 1965}

\section{Teigen I}

An early econometric investigation of the money supply relationship was that of Ronald Teigen." His study does not develop the detailed specifications which are characteristic of more recent studies. In particular, the stocks of currency in the hands of the public and demand deposits at nonmember banks are assumed exogenous. ${ }^{10}$ In addition, Teigen takes the quantity of time deposits at member banks and gov-

${ }^{8}$ For a discussion of impact versus long-run responses, see Arthur S. Coldberger, Impact Multipliers and Dunamic Properties of the Klein-Goldberger Model (Amsterdam: NorthHolland, 1959).

${ }^{9}$ Ronald L. Teigen, "Demand and Supply Functions for Money in the United States: Some Structural Estimates," Econometrica (October 1964), pp. 476-509.

10It is necessary to distinguish here between the construction of the model from historical data, and the use of the model to determine interest elasticities. In the construction of the model, the ratio of currency to demand deposits at member banks and the ratio of demand deposits at nonmember banks to those at member banks are in fact exogenous variables which vary from one observation to the next. In ernment deposits at member banks as exogenous variables. ${ }^{11}$

Teigen tests the hypothesis that the banking system takes more than one period to respond to changes in interest rates, but this hypothesis is rejected for the post-war data. Thus his impact and equilibrium interest elasticities of the money supply relationship are equal. His estimated coefficients of elasticity are 0.1950 for the commercial paper rate and -0.1695 for the discount rate. ${ }^{12}$

\section{DeLeeuw I}

Frank DeLeeuw attempted to obtain more detailed numerical estimates of behavior in important financial markets than did Teigen. ${ }^{13}$ In particular, DeLeeuw separates bank borrowing and excess reserve behavior, and explicity estimates functions for currency demand and time deposit demand at commercial banks by the nonbank public.

The interest elasticity estimates from this study are summarized in Table I. In all cases the absolute value of the long-run elasticities are less than one, and the short-run elasticities never exceed 0.2 in absolute value. The available data do not permit reconstruction of the interest elasticities of excess reserves. However, DeLeeuw did publish the results of a computation of the implicit interest elasticities of the money-reserve

determining the value of the elasticity of the relationship, these exogenous variables are kept fixed at some point, conventionally their mean value for the sample period.

Hence, the computations implicitly assume positive interest rate responses for the public's currency demand and the supply of demand deposits by nonmember banks, which are equal to the interest rate response of demand deposits supplied by member barks. For nonmember banks, the as. sumption probably does not seriously affect the analysis. On the other hand, the public's currency demand is usually found to have a zero, or slightly negative, interest elasticity, at least in the long run. If the true interest elasticity of currency demand is zero, then the bias introduced by the constant ratio of cimrency to money stock is indeterminate. On the one hand the direct effect of increased currency in the hands of the public as demand deposits supplied by banks increase biases the interest elasticity of the money supply upward. On the other hand, the indirect effect that the assumed increase in currency withdraws reserves from the banking system causes the model to understate the desired amount of deposit expansion. Since the magnitudes involved are small, the net bias should not be substantial.

$11^{\text {Th}}$ hese variables do not explicitly appear in his model. However, the reserve aggregate which he uses is unborrowed reserves available to support private demand deposits. Later studies use more broadly defined aggregates such as unborrowed reserves, or unborrowed reserves plus currency. To make the studies comparable, the model must be reformulated with time deposits at member banks and government deposits at member banks explicitly appearing as exogenous variables.

玉2Teigen, "Demand and Supply Functions," p. 502.

13Frank DeLeeuw, "A Model of Financial Behavior," in The Brookings Quarterly Econometric Model of the United States, ed. James S. Duesenberry et al, (Chicago: Rand MoNally, 1965), chap. 13. 


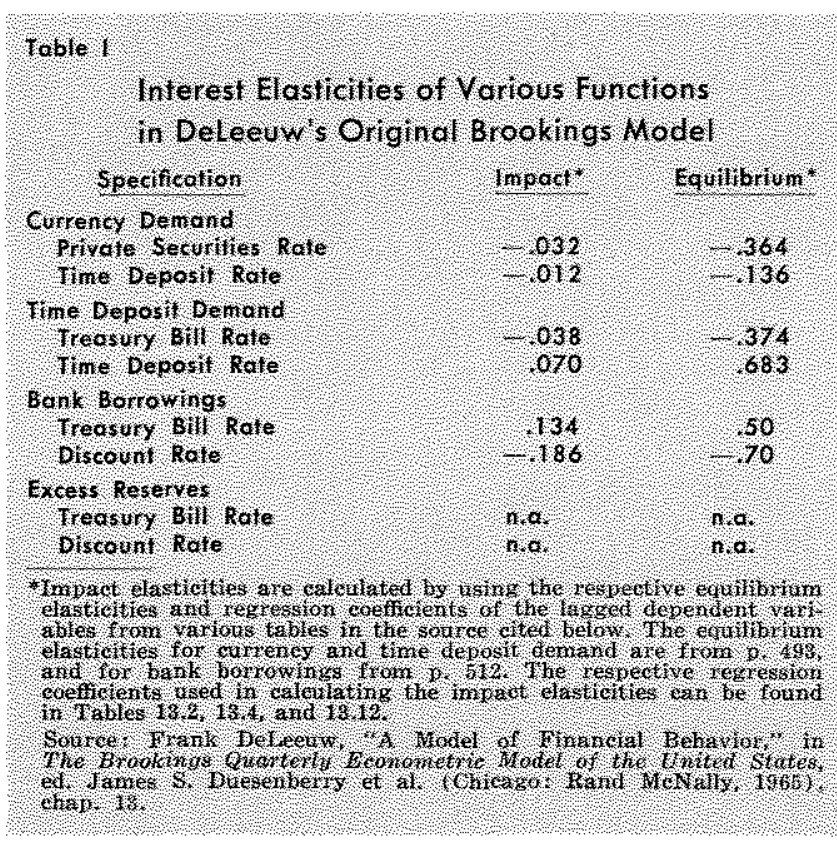

relationship derived from the estimated borrowings and excess reserves functions. In this computation, he takes the ratios of currency, time deposits, U.S. Government deposits, and nonmember bank demand deposits to money stock as constant. Thus the biases which were introduced into Teigen's computations are again present here. DeLeeuw's reserve aggregate is nonborrowed reserves plus currency in the hands of the public. His estimated long-run elasticities, valued at the sample means, are 0.172 and -0.214 for the Treasury bill rate and the discount rate, respectively. When valued in 1962 (the end of his sample period) these elasticities are 0.245 and -0.348 , respectively, ${ }^{14}$

These numbers seem quite compatible with those obtained by Teigen for approximately the same sample period. However, DeLeeuw finds that the entire adjustment of banks to portfolio changes takes place only gradually over time, and his impact elasticities for borrowings are only about one-fourth of the equilibrium values. This suggests that if the data were available to compute the short-run elasticity for the money supply relationship, the estimates over a onequarter period would be considerably lower than those obtained by Teigen.

The currency and time deposit demand equations which Deleeuw incorporates into the above computations are almost completely insensitive to interest rate changes over a one-quarter horizon. This implies that over a one-quarter horizon changes in reserves available to support private demand deposits, which are caused by interest induced changes in currency and

14Ibid, p. 518. time deposit demand, are negligible. Thus, it is highly probable that the assumptions of constant currency/ money stock or time deposit/money stock ratios result in a net upward bias in the computed interest elasticity of the money supply relationship.

\section{DeLeeuw II}

In a subsequent study for the Brookings model DeLeeuw produced a condensed model of financial behavior in which the excess reserve and borrowings equations were aggregated into a single function to explain free reserves. ${ }^{15}$ In that study estimates of the interest elasticity of the money supply relationship are not provided. However, using the free reserveinterest rate coefficient estimates and information given in the earlier study it is possible to replicate the computations of the larger model. ${ }^{16}$

The estimated impact elasticities at the sample means are 0.037 for the Treasury bill rate, and -0.046 for the discount rate. ${ }^{17}$ The corresponding long-run elasticities are 0.096 and -0.118 respectively. The $a b-$ solute values are lower by a factor of almost fifty percent from the values obtained in the earlier study, even though the data and the sample period have remained essentially unchanged.

It is likely that some downward bias has been introduced into these estimates by aggregating excess reserves and borrowings into free reserves in the estimation of the model. From the information presented in the first study, it is not possible to aggregate the interest elasticities of these two components. However, the early work suggests that the response of banks to a disequilibrium in borrowings from the Federal Reserve is much faster than the response to a similar situation with respect to excess reserves.

\section{Goldfeld}

The most detailed study of financial markets is found in the work of Stephen Goldfeld. ${ }^{18}$ In this study, equations are specified for both the demand for excess reserves and the demand for borrowings from: the Federal Reserve System. Separate equations are estimated for country banks and city banks.

The Goldfeld results suggest very large (in absolute value) interest elasticities for the borrowings equations

15Frank DeLeeuw, “A Condensed Model of Financial Behavior," in The Brookings Model: Some Futher Result, ed. James S, Duesenberry et al. (Chicago: Rand MeNally, 1969), pp. $270-315$.

"Deleeuw, "A Model of Financial Behavior."

"Unless otherwise stated, data cited have been computed by this author.

sStephen M. Goldfeld, Commercial Bank Behavior and Economic Activity (Amsterdam: North-Holland, 1966). 
relative to those found by DeLeeuw. There do not appear to be large differences in the impact elasticities of borrowings across the bank classes, but the speed of adjustment to interest rate changes is much slower for borrowings by country banks than for city banks. This is reflected in the lower impact elasticities and the higher equilibrium elasticities for the country banks than the corresponding numbers for the city banks.

The excess reserve interest elasticities reported by Goldfeld are negligible, particularly when compared with the borrowings elasticities. In addition, he finds that banks respond quite quickly to disequilibrium in excess reserve holdings. Thus, the long-run elasticities for excess reserve demand are not much different from the impact elasticities, particularly for city banks. This result is similar to that of the Teigen study where no evidence of a distributed lag in bank response was found.

Goldfeld reports interest elasticities of a money supply relationship comparable to that derived by both Teigen and DeLeeuw. The impact elasticities, with respect to the Treasury bill rate and the discount rate in this function, 0.042 and -0.029 , respectively, are derived from the elasticities reported in Table II. The corresponding long-run elasticities are 0.222 and $-0.076 .^{19}$ These results are quite close to the values reported by both Teigen and DeLeeuw for the Treasury bill rate, but considerably below the estimates for the discount rate in the other studies.

The sources of the differences are fairly conspicuous. In Teigen's study, where there is no disaggregation of excess reserves from borrowings, the Treasury bill rate and the discount rate appear only as the differential between the two rates. Hence the regression coefficient of the discount rate is constrained to have the same absolute value, but with the opposite sign from that of the bill rate. Since the mean of the discount rate for the sample period is slightly larger than that of the bill rate, the computed coefficient of elasticity of the discount rate is, in effect, constrained to be slightly smaller in absolute value than that of the bill rate. DeLeeuw constrains this excess reserve specification to include only the differential between the bill rate and the discount rate. Given the constraints that are imposed in the estimation of the Teigen and DeLeeuw studies, it would seem reasonable to conclude that the Goldfeld estimate of the response of the money supply relationship to discount rate changes is more reliable for this period.

9lbid, p. 191 .

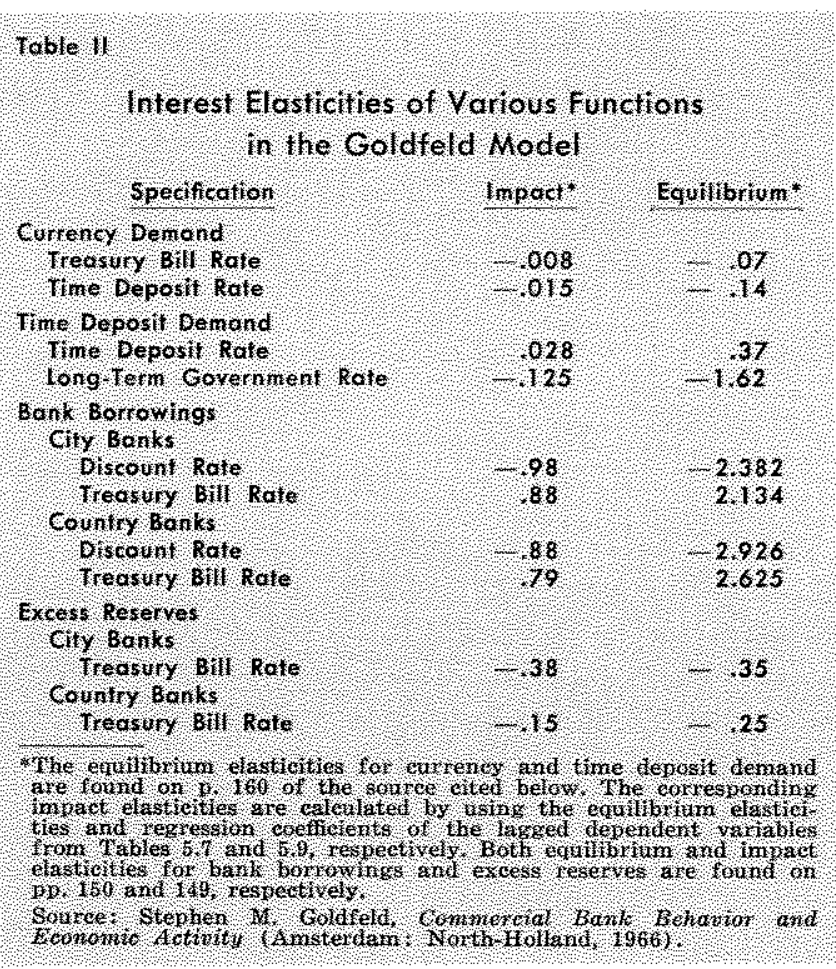

There seem to be no major discrepancies in the estimated long-run responsiveness of the money supply to changes in the bill rate, but considerable variance exists among the short-run elasticity estimates. The most uncertain issue, on the basis of the evidence reviewed so far, is the source of the interest elasticity. Goldfeld suggests that the source is bank borrowing behavior, DeLeeuw suggests that it is bank behavior with respect to excess reserves, and Teigen does not attempt to discriminate between the two.

\section{Goldfeld and Kane}

There exists an additional study by Goldfeld and Kane which provides some independent information on the question of the interest elasticity of bank borrowings from the Federal Reserve. ${ }^{29}$ This study is based on weekly data from the period July 1953 to December 1963 and disaggregates banks into four classes - New York City, Chicago, Other Reserve City, and Country banks. They find that the estimated short-run (one week) Treasury bill rate elasticities range from a high of 0.56 for New York City banks to a low of 0.08 for Chicago banks. When aggregated over all classes of banks, the short-run interest elas-

\footnotetext{
20Stephen M. Goldfeld and Edward J. Kane, "The Deterninants of Member-Bank Borrowing: An Econometric Study," Joumal of Finance (September 1966), pp. 499-514, and Stephen M. Goldfeld, "An Extension of the Monetary Sector," in The Brookings Model: Some Futher Results, ed. James S. Duesenberry et al. (Chicago: Rand MoNally, 1969), pp. 317-360.
} 
ticity for the banking system as a whole is found to be 0.21 . Their reported long-run interest elasticities of borrowings range from 2.8 to $3.9 .^{21}$.

These estimates seem consistent with the results of the quarterly study by Goldfeld and tend to add to the uncertainty of the high excess reserve and low borrowings elasticities reported by DeLeeuw. The only difficulty in reconciling the weekly estimates with the quarterly work of Goldfeld is the implied definition of long run. In the quarterly study, the long run is achieved only after serveral quarters have elapsed. In the weekly study, the implied long rum is a period of several weeks. The possibility remains that long run in the two studies has two different meanings. However, it seems safe to conclude that borrowing behavior of banks is an important source of interest elasticity of the money supply relationship when the Treasury bill rate changes and the discount rate remains constant.

\section{Teigen $I I$}

A quarterly study which deals with the period of the 1950 s through the early $1960 \mathrm{~s}$ is that of Teigen ${ }^{22}$ The study contains supply elasticities only for the demand deposit component of the money supply. The results for the elasticity of the discount rate are not very different from those reported by Goldfeld, but the elasticity of the Treasury bill rate is considerably lower than the results obtained by Goldfeld, DeLeeuw and Teigen's earlier results.

\section{Brunner and Meltzer}

Karl Brunner and Allan Meltzer have estimated the interest elasticity of the money supply relationship using annual data over a sample period including the interwar and post-war periods."23 In the two stage least-squares estimates of their "nonlinear" money supply hypothesis, they find that the elasticity of the money supply function with respect to the adjusted monetary base is insignificantly different from one. Therefore, the interest elasticities of this function can be interpreted as interest elasticities of the reserve multiplier. Their estimate of the Treasury bill rate elasticity is 0.66 and the estimate of the discount rate elasticity is $-0.31 .^{24}$ Since there are no lagged varia-

\footnotetext{
${ }^{21}$ Goldfeld and Kane, "The Determinants of Member-Bank Borrowing: An Econometric Study," p. 512.

22Ronald L. Teigen, "An Aggregated Quarterly Model of the U.S. Monetary Sector, 1953-1964," in Targets and Indicators of Monetary Policy, ed Karl Brumier (San Francisco: Chandler Publishing Company, 1969), pp. 175-218.

a Karl Brunner and Allan H. Meltzer, "Some Further Investigations of Demand and Supply Functions for Money," Journal of Finance (May 1964), pp. 240-283.

2sIbid, p. 277 .
}

bles in the equation, these estimates can be compared with the equilibrium elasticities derived from the studies which used shorter time intervals. Both elasticities appear to differ from the implied equilibrium values of the quarterly studies by a factor of over two. Given the many difficulties in estimating distributed lag effects from time series data, such inconsistencies are not surprising.

\section{Estimates from Data Including Post-1965 Period}

The shortcoming of the studies discussed so far is that they are based on data generated in the $1950 \mathrm{~s}$ and early 1960s. During the 1960 s there were many changes in the environment in which the banking system operated which could have significantly altered (and presumably increased) the interest elasticity of the money supply relationship. These changes included the evolution of an active market for large negotiable certificates of deposit, the involvement of large banks in the Eurodollar market through borrowings from (or lending to) their foreign subsidiaries, and the entrance of banks into the commercial paper market through parent one-bank holding companies.

Unfortunately it is difficult to obtain empirical evidence on many of these innovations since they were effectively legislated out of existence before enough data were generated to assess their effects. The impact of the $C D$ market can be assessed, along with the responsiveness of the banking system in terms of free reserves in the $1960 \mathrm{~s}$, through the quarterly financial model in the M.P.S. model." ${ }^{25}$ In addition, estimates of the interest elasticity of the money supplyreserve relationship on a monthly basis can be obtained from a financial market model developed by Thomas Thomson and James Pierce. ${ }^{26}$

\section{Evaluation of Quarterly Money Supply Elasticities}

The quarterly M.P.S. model contains a financial sector which includes detailed specifications of the commercial loan market and the mortgage market, as well as specifications dealing with bank and nonbank behavior with respect to holdings of currency, time deposits and free reserves. The estimated elasticities for the latter set of functions are tabulated in Table

\footnotetext{
250This model is the publicly available version which developed out of the Federal Reserve-M.I.T. - Pennsylvania econometric model project.

26Thomas D. Thomson and James L. Pierce, "A Monthly Econometric Model of the Financial Sector" (A paper presented at the May 1971 meeting of the Federal Reserve System Committee on Financial Analysis).
} 


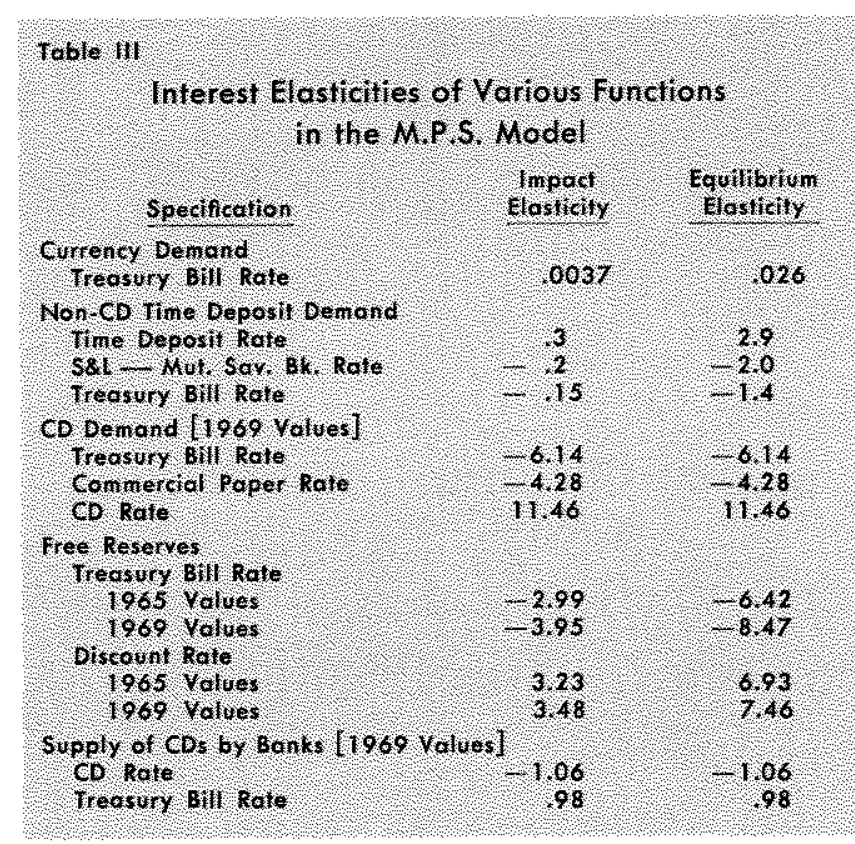

III. Both the CD demand and supply functions, which did not exist in the earlier studies, assume that the full response to an interest rate change takes place within one quarter. Thus the impact and equilibrium elasticities are equal.

The CD demand function, in particular, indicates a highly sensitive response to interest rate changes, which is consistent with casual impressions of the nature of the $\mathrm{CD}$ market. However, these estimates are drawn from a considerably smaller sample than that for the rest of the specifications, and therefore there is less certainty about the stability of the functions over time.

The estimates for the currency demand equation and the demand equation for non-CD time deposits tend to confirm the DeLeeuw and Goldfeld results of extremely low impact elasticities. The time deposit function does suggest higher long-run elasticities than had been previously estimated. This appears attributable, in part, to the evolution of special forms of time deposit accounts, such as small consumer-type CDs, during the late $1960 \mathrm{~s}^{27}$

The M.P.S. model does not distinguish between excess reserves and borrowings of member banks, but does estimate a relationship between the Treasury bill rate, the discount rate, and free reserves. No constraints are applied to the coefficients of the two rates. In Table III, both the impact and the equilibritm

27The estimated function allows for a change in structure during the early 1960 s, which indicates that the interest elasticities in the latter part of the sample period are about fifty percent higher than those estimated for the first part of the sample period. elasticities of this function are considerably higher than those estimated in the earlier studies. This is partially due to the fact that the estimated function is linear, and therefore the value of the elasticity coefficient is not constant at all points along the function. Evaluation of the elasticity coefficient at the very high values of interest rates in 1969 gives estimates of the impact and equilibrium Treasury bill rate elasticities which are fifty and twenty-five percent higher, respectively, than the values at 1965 interest rate levels. Even after accounting for the higher levels of interest rates in the late $1960 \mathrm{~s}$, it appears that differences in specifications and/or differences in sample periods have produced higher interest rate elasticity estimates for the free reserve relationship than had previously been found.

Simulation experiments were performed with the M.P.S. model which permitted relaxation of restrictions under which interest elasticities of the money supply relationship were computed in the studies discussed above. First, in addition to the impact elasticities, the pattern of response of the money stock over time to a maintained change in the Treasury bill rate was computed. The simulations were continued for eight quarters, after which the computed elasticities settled down at close to the equilibrium values.

Second, the response of the demand for currency and the demand for time deposits to the changes in interest rates can be included or excluded from the computation of the elasticities. Time deposit demand is split into large negotiable certificates of deposit and other time deposits. The inclusion of the currency and time deposit responses in the simulation is analogous to a controlled experiment in which the nonbank private sector demand for bank demand deposits is shifted once and maintained in its new position. This shift is allowed to occur without any effect on the demand functions for time deposits or currency. This shift generates an initial change in interest rates. The changes in the money stock, which are observed over time, are the result of the interest rate induced portfolio shifts by banks and the nonbank public, and they trace out the interest elasticity of the money supply relationship over various time intervals. Finally, elasticities are computed for both demand deposits and the $\mathrm{M}_{1}$ money stock concept.

The estimated elasticities from three sets of simulations are presented in Table IV. These computations are generated under the assumption that the Federal Reserve would not impose a Regulation $Q$ constraint which would prevent banks from offering new CDs at competitive rates. 
If such constraints were effective, increases in the Treasury bill rate would cause a shift in the demand for CDs. At the constrained new issue rate for CDs the public would not renew outstanding certificates as they matured. Over time the stock of CDs would decline, and there could be a sizable reduction in the ratio of time deposits to demand deposits. The change in this ratio would, in turn, cause a fluctuation in the reserve multiplier. The observed result would also be highly sensitive to the initial conditions of the Treasury bill rate relative to the Regulation Q ceiling, and the historical pattern of Regulation $Q$ restraint.

In the first section of Table IV, the interest elasticities include the interest rate induced reactions in the public's demand for currency, large certificates of deposit as well as other time deposits, and the interest elasticity of the commereial banking sector's supply function for large certificates of deposit. The interest elasticity of $M_{1}$ is consistently smaller than the interest elasticity of the demand deposit component. This is because the model indicates a small negative response of the demand for currency to changes in interest rates. Hence, as interest rates increase and the amount of bank deposits available to the economy expands, there is an offsetting movement in currency balances outstanding.

The exclusion of the nonbank private sector's demand for currency and time deposits other than large certificates of deposit lowers the interest elasticity of the money supply relationship. ${ }^{28}$ This is because a rise (fall) in interest rates decreases (increases) the quantity demanded of both of these assets. This relationship is straightforward in the case of currency. For time deposits the expected equilibrium response would be for a large quantity of time deposits to be demanded with higher levels of all interest rates. The model postulates, however, that the rate which banks offer on non-CD time deposits responds quite sluggishly to changes in market interest rates. Thus the short-run effect is for disintermediation away from commercial bank time deposits. If the elasticity patterns were computed over a longer time horizon, the elasticities in the first experiment would eventually become smaller than those for the second experiment. In all cases the impact elasticities are essentially the same size.

These results can be compared with those from earlier empirical studies which do not include the CD

\footnotetext{
28This exclusion of currency and time deposit demand allows these demand functions to shift in such a way that the quartity demanded at the new Treasury bill rate is exactly equal to the quantity demanded at the original level of the Treasury bill rate.
}

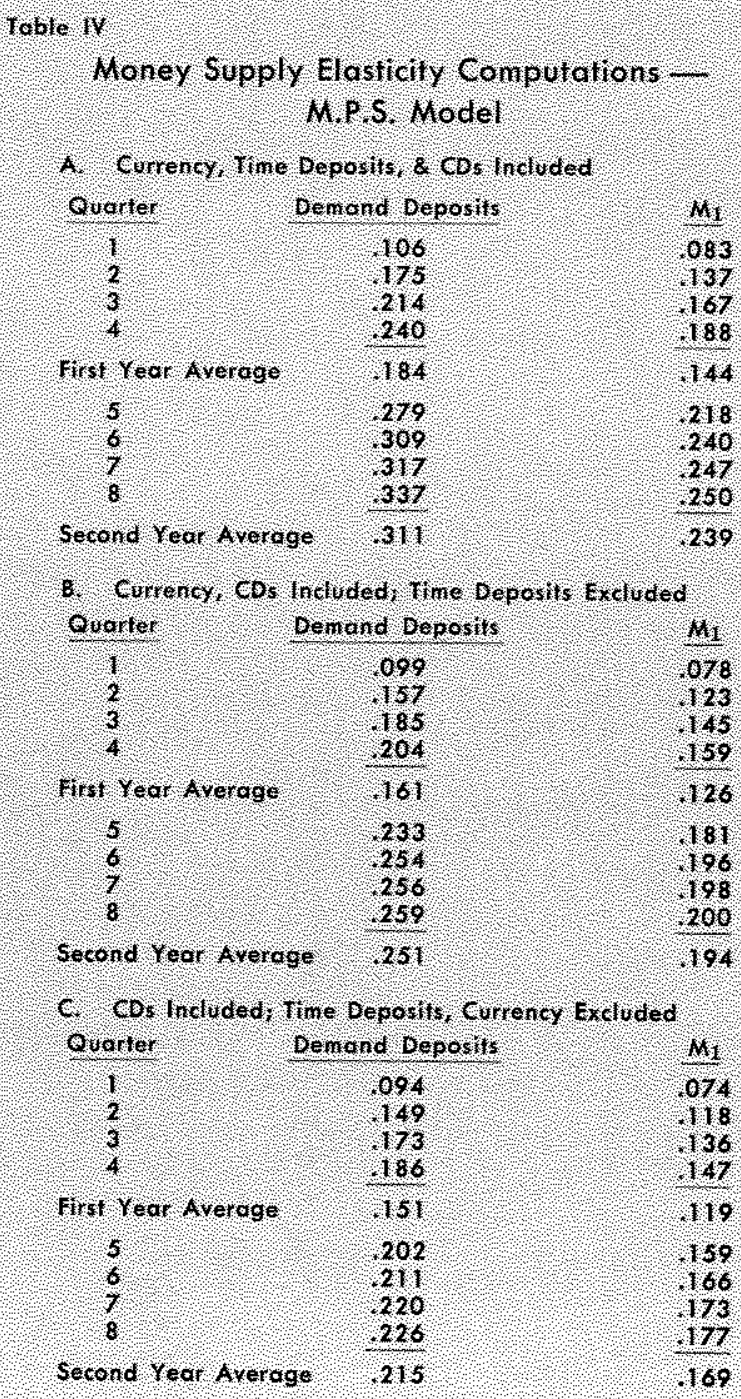

market. It appears from section $\mathrm{C}$ of Table IV that when the CD market is operating freely, the estimated interest elasticity of the money supply relationship differs little from the results drawn from studies of earlier periods. If anything, the elasticities reported in this section of the Table are generally lower than those discussed above. On the other hand, sections A and $B$ of Table IV suggest that the net bias involved in computing the interest elasticities with a constant currency/deposit ratio and a constant level of time deposits tends toward zero. That is, the estimates obtained under these assumptions give estimates of elasticities which are too low.

\section{Evaluation of Monthly Money Supply Elasticities}

The same type of analysis of the money stockreserve relationship as that performed with the M.P.S. 
quarterly econometric model can be carried out on a monthly basis using the financial market model of Pierce and Thompson. The results over an eighteen month period are presented in Table $V$. In this model, demand for currency by the public is specified to be completely interest inelastic, so the assumptions underlying the calculations of sections $\mathrm{B}$ and $\mathrm{C}$ of Table IV are identical to the assumptions made for the right-hand column of Table $\mathrm{V}$. The analogy to section A of Table IV is presented in the left-hand column of Table $\mathrm{V}$.

The implication of the monthly model is that the money stock - reserve relationship is slightly more elastic in the short run than the various quarterly estimates imply. The implied impact elasticity (over a one-month period in this case) is about 0.15 . The average elasticity over this first twelve months is estimated at about 0.25 , or about one-third more than the estimate over the corresponding four-quarter horizon from the M.P.S. model. After eighteen months have elapsed the elasticity values reflect the long-run, or equilibrium, values. This horizon agrees reasonably well with the horizon of the M.P.S. model.

\section{Conclusions}

It is difficult to draw a finely defined set of conclusions from the set of studies which have been examined. There exists a range of elasticity estimates among these studies which cannot be reconciled with the information which is readily available at the present time.

However, while a single point cannot be established as the most probable value for the interest elasticity of the money supply, it appears that the studies do provide information which can be of value in policy discussions concerning the control of the money stock. A broad, but valuable conclusion is that the interest elasticity of the money supply during the sample period of these studies appears to be extremely low. It seems appropriate to conclude with almost complete certainty that the long-run elasticity during this period was less than 0.5 and that the impact elasticity (one quarter) was probably no greater than 0.10 to 0.15 . All these elasticities are relevant for policy actions which result in changes in the Treasury bill rate, while leaving the discount rate unchanged.

For the class of policy actions which simultaneously alters the Treasury bill rate and the discount rate by the same amount from an initial position where the two are approximately equal, it is the sum of the interest elasticities of the money supply which is rele-

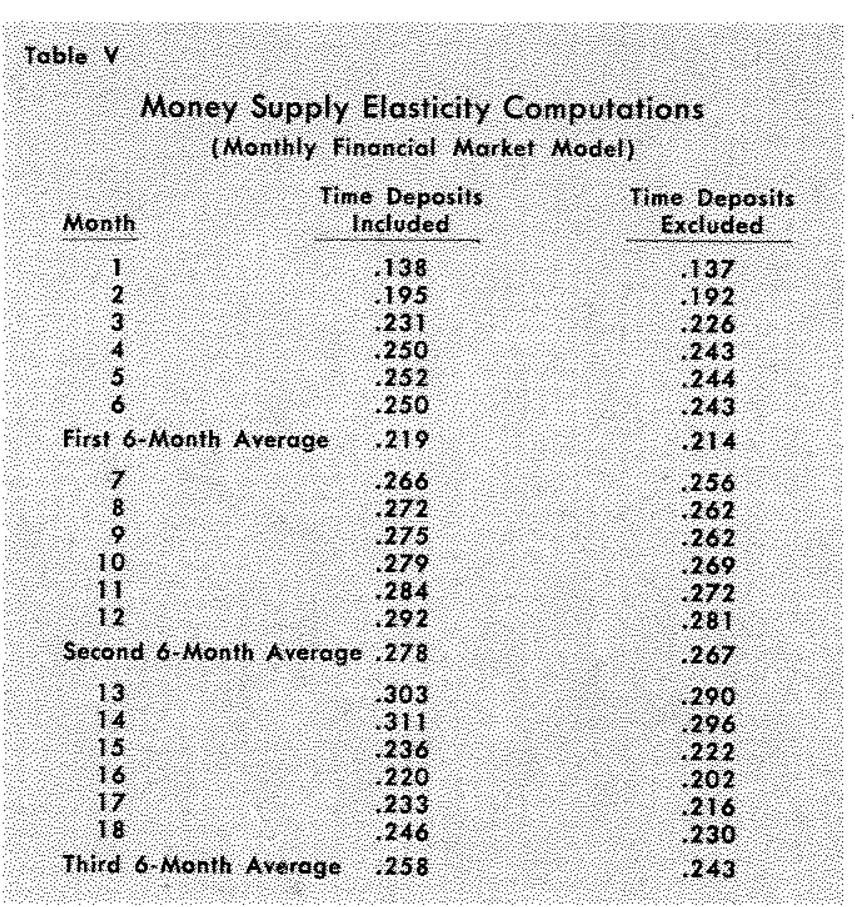

vant. Two of the studies suggest that the elasticity with respect to the discount rate is slightly smaller than that with respect to the bill rate. The estimation of these relationships involves constraints on parameters, and hence, is not a valid test of the hypothesis that the two elasticities are significantly different. In the Goldfeld study, where there are no constraints imposed on the estimated parameters, the estimated coefficient of elasticity for the discount rate is considerably smaller in absolute value than that of the bill rate. Therefore, it would appear that while the interest elasticity of the money supply relationship is likely to be smaller when both rates are changed simultaneously, it is almost certain that the coefficient of elasticity will remain positive. Furthermore, the elasticity under such a policy probably does not exceed one-half to two-thirds of the interest elasticity under a policy of keeping the discount rate fixed.

The available evidence suggests quite conclusively that the short-run feedbacks through interest rate changes, which would be generated by policy changes in reserve aggregates, are very weak and should cause little, if any, difficulty for the implementation of policy actions aimed at controlling the money stock through the control of a reserve aggregate. Of course, the size of random fluctuations in the reserve multiplier remains a major factor in determining the size of deviations of the money stock from its targeted value. An issue which remains to be investigated is the size of the variance of the multipliers associated with various reserve concepts. 